\title{
Learning to Teach: 'Assessment for Learning' in Higher Education
}

\author{
Susanne Garvis, Griffith University, Australia
}

\begin{abstract}
When you start teaching at a university, there is no handbook on what to do (Mueller, 2003). It is assumed that prior experience as a teacher provides you with suitable skills to teach adult learners. The needs of adult learners, however, can be very different. This self-study explores my initial entry into teacher education and the changes that I have had to create pedagogy with adult learners. I have focused particularly on assessment. The self-study acted as a form of professional learning and provided me with new ways to position my teaching using assessment. Findings suggest my new approach for feedback to assessment helped improve student learning and outcomes. It also allowed me to see my own efficacy in being able to change my teaching approach.
\end{abstract}

Keywords: Assessment, Beginning Teacher

\section{Introduction}

A ssessment is an important element of quality teaching and learning in higher education. It provides opportunities for students to have coherent educational experiences. In Australia, assessment in higher education has received significant focus. In particular, there has been an emphasis on providing guidelines and principles to develop effective assessment practice. Academics have a critical role to play to provide carefully designed assessment that contributes to providing quality educational experiences for students. As a beginning teacher educator however, it is difficult to find out about ways to improve assessment practice in your teaching. With no handbook, limited courses and the strong concept of 'working in isolation', assessment is often left to the individual teacher educator.

This self-study explores ways improve assessment practice in my teaching. When I first entered teacher education, I realized many of the tasks 'set students up to fail'. As a former early years educator of five years, I did not want to continue teaching in this unsupported role. I decided to implement a concept of 'assessment for learning' to help improve student learning and understanding. Using a narrative approach, I was able to document the transformation in my teaching practice for assessment over the year. Findings suggest that by providing quality feedback to students in a variety of approaches, student learning and outcomes improve. This self-study has also acted as a form of professional learning, allowing me to realize the importance of exploring my own teacher education practices and my own efficacy for change.

\section{Literature}

\section{Beginning Academic Life}

There is no manual on how to be a teacher educator (Mueller 2003). When teacher educators enter the university they are given a relatively large degree of control over their professional work and it is generally assumed that, as they know how to teach, that they also know how to educate teachers. Even though there is frequent talk about creating supportive networks to encourage professional learning, few examples exist within the literature describing the ways in which universities support teacher educators. Furthermore, the realities associated with teaching at a university can be a very professionally isolating experience, their increasingly intensified

The International Journal of Humanities Education Volume 10, 2013, www.thehumanities.com, ISSN 2327-0063

(C) Common Ground, Susanne Garvis, All Rights Reserved Permissions: cg-support@commongroundpublishing.com 
workload resulting in limited time to discuss concerns or challenges with other staff members (Mueller 2003).

As an Australian early-career academic, limited opportunities are provided for personal learning in teaching. This is worrying, considering it is predicted that in the next few years in Australia there will be a shortage of academics in all disciplines (Hugo 2008). As an early-career teacher educator, you are often in isolation, with limited opportunities to collaborate with peers and observe teaching practice. There is also limited opportunities and time for professional learning. As Murray and Male (2005) have shown, that there is little in the way of induction and professional learning for teacher educators.

Zeichner identified that teacher educator researchers have a special responsibility in preparing the new generation of teacher educators and for generating new knowledge about how to do the work of teacher education more effectively:

If this new generation of teacher educators goes into their roles with knowledge of the scholarly literature related to the work of teacher education and with the dispositions and skills to study their practice it will make it better for novice teachers and their pupils will benefit. (Zeichner 2005, 118)

As a beginning teacher however this is difficult. As Zeichner explains when he first began teaching, he "was not aware at that time that there was an emerging literature on teacher education and that people had thought about the issue of teacher learning apart from the issue of learning in general" (Zeichner 2005, 118). He is concerned that "many universities today treat teacher education as a self-evident activity both for school and university-based teacher educators" (118).

Many beginning teacher educators have a number of roles to fulfill including pastoral care and administration. To establish their position in the university, some beginning teacher educators appear to work hard (Mayer, Mitchell, Santoro and White 2011) Archer (2008) calls the discourse of 'flogging oneself', a common discourse within academe. Within Australia, this is compounded by recent changes in research accountability measures such as the Excellence in Research for Australia (ERA) assessment (which was initiated by the Australian government in 2010 and is designed to assess research quality within Australia's higher education institutions), there is greater scrutiny of universities and intensified pressure for teachers educators to research and publish.

Little attention is also given to the identity of beginning teacher educators as they look te reestablish their teaching in the higher education context. However, what often followed was a process of 'negotiating credibility', 'reconstructing themselves' and determining 'being effective' (Ramage 2005). Murray and Male's (2005) found that it 'took between two and three years to establish professional identities as teachers of teachers . . . a long and sometimes difficult process' (134).

\section{Assessment Feedback}

As a beginning teacher-educator, you are given limited training in suitable assessment techniques and strategies for adults. From my experience as an early childhood educator, I realize the importance of detailed feedback to students. I drew on my past experience as a teacher to try and work out suitable ways to deliver feedback to adults.

Feedback is an important element of assessment in higher education. Nicol and MacfarlaneDick (2006) outline seven principles for effective feedback that are based on their synthesis of the extensive literature in this area. They suggest that good feedback:

1. Helps clarify what good performance is (goals, criteria, expected standards);

2. Facilitates the development of self-assessment in learning;

3. Delivers high quality information to students about their learning; 
4. Encourages teacher and peer dialogue around learning;

5. Encourages positive motivational beliefs and self-esteem;

6. Provides opportunities to close the gap between current and desired performance;

7. Provides information to teachers that can be used to shape teaching. (205)

Hattie and Timperley (2007) come to similar conclusions, providing a model for understanding the potential for feedback to improve learning. First, they suggest that teachers need to reduce the discrepancies between students' current understandings and the desired goal. Ways in which this may be achieved include students increasing effort, employing more effective strategies, or abandoning, blurring or lowering the goals; or by teachers providing appropriate and specific goals and supporting the students in reaching them through effective learning strategies and feedback. Hattie and Timperley suggest that effective feedback answers three orienting questions: Where am I going (feed-up), how am I going (feed-back) and where to next (feed-forward).

\section{Feedback: How Am I Going?}

The word feedback is often used as an all-encompassing term for all aspects described by Hattie and Timperley (2007) and Nicol and Macfarlane-Dick (2006). Hattie and Timperley (2007) define feedback as "information provided by an agent (e.g., teacher, peer, book, parent, self, experience) regarding aspects of one's performance or understanding” (81). Similarly, Irons (2008) defines feedback as any comments that are provided to the students from which they can learn. Eventually they will learn to provide themselves with feedback as they build and reflect on their own conceptions of quality.

\section{Feed-forward: Where to Next?}

Irons (2008) describes feed-forward as comments provided for work in progress, allowing students to enhance their work in the future. The process allows students to reflect on their current levels of achievement and devise plans for improving their current standard.

\section{Feed-up: Where Am I Going?}

As Nicol (2008) and Sadler (1998) argue, students need to understand what quality work looks like if they are to be able to produce it. This means providing examples of various standards to the student for viewing. "Students need to develop a conceptualisation of what constitutes 'quality' as a generalised attribute” (Sadler 2009a, 178). Students need to be provided with opportunities to engage in making multiple holistic judgments of complex works (peer and teacher responses to the same task). After each judgment, students position themselves in understanding the nature and function of the criteria that they employ. Recent studies (Handley \& Williams 2009; Orsmond, Merry \& Reiling 2002) suggest students are receptive to complex works and value class discussion around standards of assessment.

Adopting the view that "assessment is the learning", I have sought to embed these skills within the learning experiences and the assessment tasks. My practice is based on widely agreed, theoretical ideas derived from the literature, which from my viewpoint as a beginning teacher educator, seem to still have limited implementation in higher education settings. The value of formative assessment (Irons 2008) and effectiveness of feedback (Hattie \& Timperley 2007; Sadler,1998; Yorke 2003) has been confirmed in the literature, but traditional assessment tasks such as set-topic essays, multiple choice and short answer exams continue to dominate higher education practice. Many of these assessment practices have been used because they allow for time-efficient marking. 


\section{Focus of Study}

As a beginning teacher educator, the idea of designing rigid assessment tasks that "teach students a lesson” (through failure) was an alien concept. I didn't set my kindergarten students up to fail; likewise I did not feel comfortable settings adults up for failure. As a teacher (in teacher education), I position myself in partnership with the students: I want my class to succeed as students and beginning teachers. I view my role as a teacher educator as also modeling professional learning habits and assessment techniques for future teachers. I want the students in my courses not only to do well, but I want the concept of 'assessment for learning' to facilitate the development of skills in critical thinking and reflection to enable self-monitoring and selfcorrection as beginning teachers.

As a beginning teacher educator, I was unaware of how to mend what I was experiencing. The focus of this self-study is my initial reactions to a problem with assessment with courses I had taken over when I started. The focus of the study is to map my techniques used in delivering 'assessment for learning' and to explore the influence of my own pedagogical intent.

\section{Method}

This research employs a self-study approach. Self-study through reflective practice is the thoughtful, systematic, critical, exploration of the complexity of one's own learning and teaching practice (Dinkelman 2000; Samaras \&Freese 2006). Reflective practice can be both intellectual and affective (Stockhausen and Kawashima 2002, 119), and "has the potential to facilitate transformed practice" $(2002,118)$. Reflection is a process to which teacher educators bring their personal practical knowledge and their voice (Godson \& Walker 1991).

I draw on Dewey's ideas that it is through the reconstruction of meaning, reflection and deliberation that growth can occur (Dewey 1934; 1938), stimulating the development of reflective practice (Campbell \& Norton 2007). Russell (2005) identifies self-study as a challenging process for teacher educators, through which teacher educators critically reflect on their practice and make changes that (they hope) will improve their practice. Improving my practice was the goal of this study.

I kept a reflective journal over the course of a year to document key events in my teaching. In it I wrote of experiences, my measured performance and observations of student learning. I revisited these events at the end of the year to analyse what change took place. My initial decision to keep a journey was based on seeking an understanding of my teaching practice as I tried to cater for the learning needs of adults in higher education. From this I selected key narrative events that signify my growth in understanding about feedback in assessment.

\section{Findings}

In my first year as a full-time academic, I was given the responsibility of convening a new program: the Graduate Diploma in Early Childhood Education. In an effort to increase the number of qualified teachers working in early childhood, the program was intended for students holding a non-education degree to study full time for one year to become a registered early childhood teacher. Commonwealth Government supported places were available to suitable applicants.

The goal of my self-study was not only to improve the quality of students' work in my subject, but also develop the skills needed to be a teacher. I identified these skills as assessing and evaluating, how to write feedback/how to read/interpret feedback. I wanted to really help the students learn. This was my first full time year in teaching higher education.

The program promotes alignment between theory and practice, leading to informed and reflective practitioners. Despite minor differences in timetabling in the curricula at each campus, 
each program consists of core subjects dedicated to the development of knowledge and skills required for early childhood education. The program consists of education (informing discipline) studies (one course per semester), curriculum studies (two courses per semester) and professional experience (one course per semester) with an additional 50 hours of wider professional experience to be completed over the course of two semesters in schools, kindergartens and child care centres.

For many university students, assessment is closely aligned to the quality of teaching and learning that takes place. According to James, McInnis and Devlin (2002), there should be three interrelated objectives for quality in student assessment in higher education. These are:

1. Assessment that guides and encourages effective approaches to learning;

2. Assessment that validly and reliably measures expected learning outcomes, in particular the higher-order learning that characterises higher education; and

3. Assessment and grading that defines and protects academic standards.

When these objectives are aligned with assessment items in the Graduate Diploma ECE, the disjuncture between theory (task) and practice (professional experience) become apparent. The poorly designed assessment may hinder learning and curriculum innovation.

The Graduate Diploma ECE was created on the foundation of a theory-practice approach, with a range of criteria-based assessment. Assessment was intended to be linked to implementation of activities during professional experience. In the first semester, students undertake a four-week block of professional experience in a school. In the second semester, students undertake a six-week block in a school. During the first semester I kept personal diary about what I was seeing. Below was an insert from an initial entry:

During semester one, 2010, I began to notice that students in my courses had difficulty understanding criteria and knowing how to use feedback when it was given on assessment items. I opened my eyes and became conscious of how my students were learning. Criteria appeared to be written in an alien language! Students were confused about the different levels of achievement written in assessment tasks. I hadn't created this program but it was my responsibility to do something about it.

After reading and re-reading the entry, I decided to investigate the literature to find strategies to help reduce the assessment and feedback problem the students and I was experiencing. From this I was able to identify actions that might help my students in their understanding.

1. Research suggests that students find it difficult to interpret written feedback (Nicol 2008; 2010; Ivanic et al 2000)

In order to address this, I dedicated time during tutorials to discussing feedback verbally regularly throughout the semester. The students completed formative assessment tasks during tutorials and these were marked by their peers and myself.

2. Sadler (2009) identifies that students often don't have a holistic understanding of what the criteria mean and how they are interpreted by those marking their work. Through the formative assessment tasks, we interpreted the criteria together and developed shared understandings of the quality that each standard represented.

After introducing these approaches in my teaching, the students began to understand and reflect on the importance of assessment, showing their teacher knowledge developing. This approach constructed a shared understanding between myself and the students about what each criterion meant. It also provided opportunities for students to engage in the experience of marking assessment- something they will be doing regularly as a teacher in a classroom. A shared understanding was also reached about interpreting feedback and using feedback to improve the next assessment items. Students started to realise the importance of feedback on assessment items and how it could be used for improvement. 
On evaluation of this trial in my teaching, I drew on four sources of data; teaching evaluations, tutor feedback, student email feedback and my own personal observations that provided evidence of the improvement in my teaching for assessment and feedback. The two courses involved received two commendations for SEC results greater than 4.5. Pre-service teacher reflections in teaching and course results included:

The assessments left no stone unturned. Very comprehensive and engaging. I probably learned the most from them, as I had to apply all the theory we were learning to real life context. Case studies, reflective journals...clever assessment that made sure every aspect of the course content was covered and reflected in it. Observation and studying children were brought to life. As strange as it sounds, I have absolutely loved the assessments. I'm not convinced I am going to pass them all, but I have loved being challenged by them, all the same.

Susie has an amazing ability to enhance our learning by not allowing us to simply memorise information, just to have us regurgitate it later. We actually had to digest it, access it, work things out for ourselves, and take aspects of our learning to build into our personal philosophy of teaching. She had clever ways of having us access the information we had learned on a number of levels. It's hard to explain her style....all I know is that I wasn't a passive sponge just absorbing all the course content to regurgitate it in an exam...I felt as if I was an active participant in my learning. And without a doubt, that was the most valuable lesson I learned.

Students also valued assessment items being linked to the classroom context. In order to complete the task, students must enter a classroom and observe and analyse a child's level of development. Students must talk to the teacher and parent throughout the assessment task.

I really liked that the observation assessment tied in with practical placement. Providing links to real life situations make the assessment seem relevant and therefore you are more eager to effectively engage with the task. The feedback really helped me.

In my own observations I have noticed changes in the thinking and understanding shared by the beginning early childhood teachers. Their thinking is deep, with much insight about the many different influences on the teaching environment. I have seen strong construction around their own teacher knowledge that they will draw upon. The quality of assessment items have also improved and the overall standard is closer to what is expected by registration bodies and my own expectations of what early childhood teachers should know.

In my final diary entry after the trial I wrote;

I now want to implement these strategies into more of my courses and share my experiences with my colleagues in early childhood education. I know there will always be ups and down but I really want to try

\section{Discussing and Conclusion}

Through this self-study I have tried to improve my own teaching pedagogy by exploring feedback as part of assessment. I realized that there were better ways for assessment delivery in my higher education teaching. This drive (or my intent for change) I discovered was created from previous experience assessing young children. While I did not set up young children to fail in assessment, I could not understand how university assessment could set students up to fail. Coming from a teaching philosophy based on care and scaffolding, I wanted to support the 
students in their learning as much as possible. I also wanted to model the concepts I was teaching, especially about caring and respecting individual learners.

The first noticeable change was an improvement in student work and student engagement in class. Students became more aware of the meaning of criteria and how they could demonstrate different criterion. It appeared that as I took greater ownership of assessment, students also took greater ownership of their learning. The students realized that the tasks were there to show how much they had learned in the course about early childhood education.

Another key point was linking the assessment task to the real world context. Students were able to engage with a real problem and employ a real solution. The students saw value in the feedback given to help with real world context.

By studying the way I delivered feedback, I engaged in professional learning about higher education. I searched the literature to find possible solutions before I tried to implement these into my own early childhood teacher education classes. From this experience, I learnt the importance of continually engaging in professional learning for higher education teaching. To keep my teacher registration I was expected to attend professional learning activities. As a teacher educator I wanted to continue my own professional learning about teaching. Too common I feel it is easier to become distracted by exploring literature in our own research areas, without also acknowledging that as teacher educators we must also explore changes that are occurring in teacher education practice. As a beginning teacher educator, I realized the importance of regular engagement with teacher educator journals to read about other's approaches to higher education pedagogy.

This self- study also taught me about the importance of continually studying my own teaching practice in higher education. As the majority of my academic work and teaching is conducted in isolation, it is important for me to engage in self-study to provide a 'feedback' reflection loop on my own practice. As such, I would suggest self-study is important for all teacher educators as it allows professional learning and growth. By undertaking individual studies, we can also learn from other teacher educators who work in isolation. Even as a beginning teacher educator, it provides opportunities to explore your own teaching and find ways forward.

As I have worked in isolation, it is important that I also find others interested in self-study to share and discuss my experiences in and outside of my institution.

Greater awareness is needed within universities on the importance of engaging in self-study about our own teacher practice. Before I engaged in this self-study I was unaware of how useful it was for my own professional learning. Within limited opportunities for professional learning in higher education teaching at universities, it is important for academics to find other ways to support their teaching needs. Universities would also benefit from developing hubs of self-study in discipline areas. Not only would professional learning be taking place, the quality of student learning would improve, helping fulfill the current requirements of universities to improve student satisfaction with teaching. While many of these ideas are based on recognizing the importance of higher education teaching, it is important that if we want better teachers in schools, we need to look at ways we can model and support future teachers in universities. 


\section{REFERENCES}

Archer, L. 2008. The new neoliberal subjects? Young/er academics' constructions of professional identity. Journal of Education Policy 23: 265-85.

Campbell, A., and L, Norton, eds.. 2007. Learning, Teaching and Assessing in Higher Education: Developing Reflective Practice. Exeter: Learning matters.

Clandinin, D.J., and F.M, Connelly. 2000. Narrative inquiry: Experience and story in qualitative research. San Francisco, CA: Jossey-Bass.

Dewey, J. 1934. Art as experience. New York: Milton, Balch.

Dewey, J. 1938. Experience and education. New York: Macmillon.

Dinkelman, T. 2000. An inquiry into the development of critical reflection in secondary student teachers. Teaching and Teacher Education 16 (2): 195-222.

Godson, I., and R, Walker. 1991.Biography, identity and schooling: Episodes in educational research. London: Falmer Press.

Handley, K., and L, Williams. 2009. From coping to learning: using exemplars to engage students with assessment criteria and feedback. Assessment and Evaluation in Higher Education. First published on: 02 October 2009 (iFirst).

Hattie, J. and H, Timperley. 2007. The Power of feedback. Review of Educational Research, 77: 81-112.

Hugo, G. 2008. The demographic outlook for Australian universities' academic staff. CHASS occasional paper no. 6. Adelaide: Council for Humanities, Arts and Social Sciences (CHASS).

Irons, A. 2008. Enhancing learning through formative assessment and feedback: Effective teaching in higher education. London: Taylor \& Francis Routledge.

Mayer, D., J, Mitchell, N, Santoro, and S, White. 2011. Teacher educators and 'accidental' careers in academe: an Australian perspective. Journal of Education for Teaching 37 (3): $247-260$.

Mueller, A. 2003. Looking back and looking forward: Always becoming a teacher educator through self-study. Reflective Practice 4: 67-84.

Murray, J., and T. Male. 2005. Becoming a teacher educator: Evidence from the field. Teaching and Teacher Education 21: 125-42.

Nicol, D. 2008. Learning is a two-way street. Times Higher Education, April 24.

Nicol, D. J., and D, Macfarlane-Dick. 2006. Formative assessment and self-regulated learning: A model and seven principles of good feedback practice. Studies in Higher Education 31 (2): 199-218.

Osmond, P., S. Merry, and K, Reiling. 2002. The use of exemplars and student driven marking criteria in peer and self-assessment. Assessment and Evaluation in Higher Education 27 (4): 309-323.

Ramage, C. 2005. Negotiating multiple roles: Link teachers in clinical nursing practice. Journal of Advanced Nursing 45: 287-96.

Russell, T. 2005. Can reflective practice be taught? Reflective Practice 6: 199-204.

Sadler, D.R. 1998. Formative assessment: revisiting the territory. Assessment in Education 5 (1): 77-84.

Sadler, R. 2009a. Indeterminacy in the use of preset criteria for assessment and grading. Assessment and Evaluation in Higher Education 34 (2): 159-179.

Sameras, A., \& A, Freese. 2006. Self-study of teaching practices. New York: Peter Lang.

Stockhausen, L. and A, Kawashima. 2002. The introduction of reflective practice to Japanese nurses. Reflective Practice 3 (1): 117-130.

Yorke, M. 2003. Formative assessment in higher education: Moves towards theory and the enhancement of pedagogic practice, Higher Education 45 (4): 477-501. 
Zeichner, K. 2005. Becoming a teacher educator: A personal perspective. Teaching and Teacher Education 21: 117-24.

\section{ABOUT THE AUTHOR}

Dr. Susanne Garvis: The main focus of my work at the University of Queensland has been the professional development of pre-service teachers. My research and teaching interests include teacher education and arts education, with a particular interest in music. 

The International Journal of Humanities Education

is one of five thematically focused journals in the collection of journals that support the New Directions in the Humanities knowledge community -its journals, book series, conference, and online community.

This journal explores teaching and learning in and through the humanities. The humanities encompass a broad domain of educational practice, including not only literature, language and literacy, but also at times extending as far as the various areas of social studies and the arts. Indeed, the human concerns addressed by this journal also interface deeply with learning in all subject areas, including the disciplines of the sciences and technology.

As well as papers of a traditional scholarly type, this journal invites presentations of practice-including documentation of curricular practices and exegeses of the effects of those practices.

The International Journal of Humanities Education is a peer-reviewed scholarly journal.

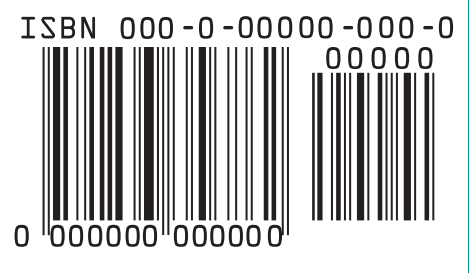

